\title{
A Peptide Nucleic Acid-Neamine Conjugate that Targets and Cleaves HIV-1 TAR RNA Inhibits Viral Replication.
}

Emmanuel Riguet, ${ }^{1}$ Snehlata Tripathi, ${ }^{2}$ Binay Chaubey, ${ }^{2}$ Jérôme Désiré, ${ }^{1}$ Virendra N. Pandey ${ }^{2^{*}}$ and Jean-Luc Décout ${ }^{1 *}$

Supporting Information

Experimental details for the synthesis of compounds 2, 6 and 7

as well as biochemical and biological assays 


\section{Synthesis}

General Procedures. Melting points are reported uncorrected. Chemical shifts are in parts per million relative to the residual signal of the solvent. Thin-layer chromatographic data $(R f$ values) were obtained with Macherey Nagel Alugram ${ }^{\circledR}$ SIL G/UV254 analytical sheets (layer: $0.25 \mathrm{~mm})$ developed with dichloromethane-methanol 95:5 $\left(R_{f}^{\mathrm{A}}\right)$ or 90:10 $\left(R_{f}^{\mathrm{B}}\right)$, pentane-dichloromethane 60:40 $\left(R_{f}^{\mathrm{C}}\right)$ or 50:50 $\left(R_{f}^{\mathrm{D}}\right)$.

Synthesis of the protected neamine derivative 6 used in the synthesis of the PNAneamine conjugate 2.

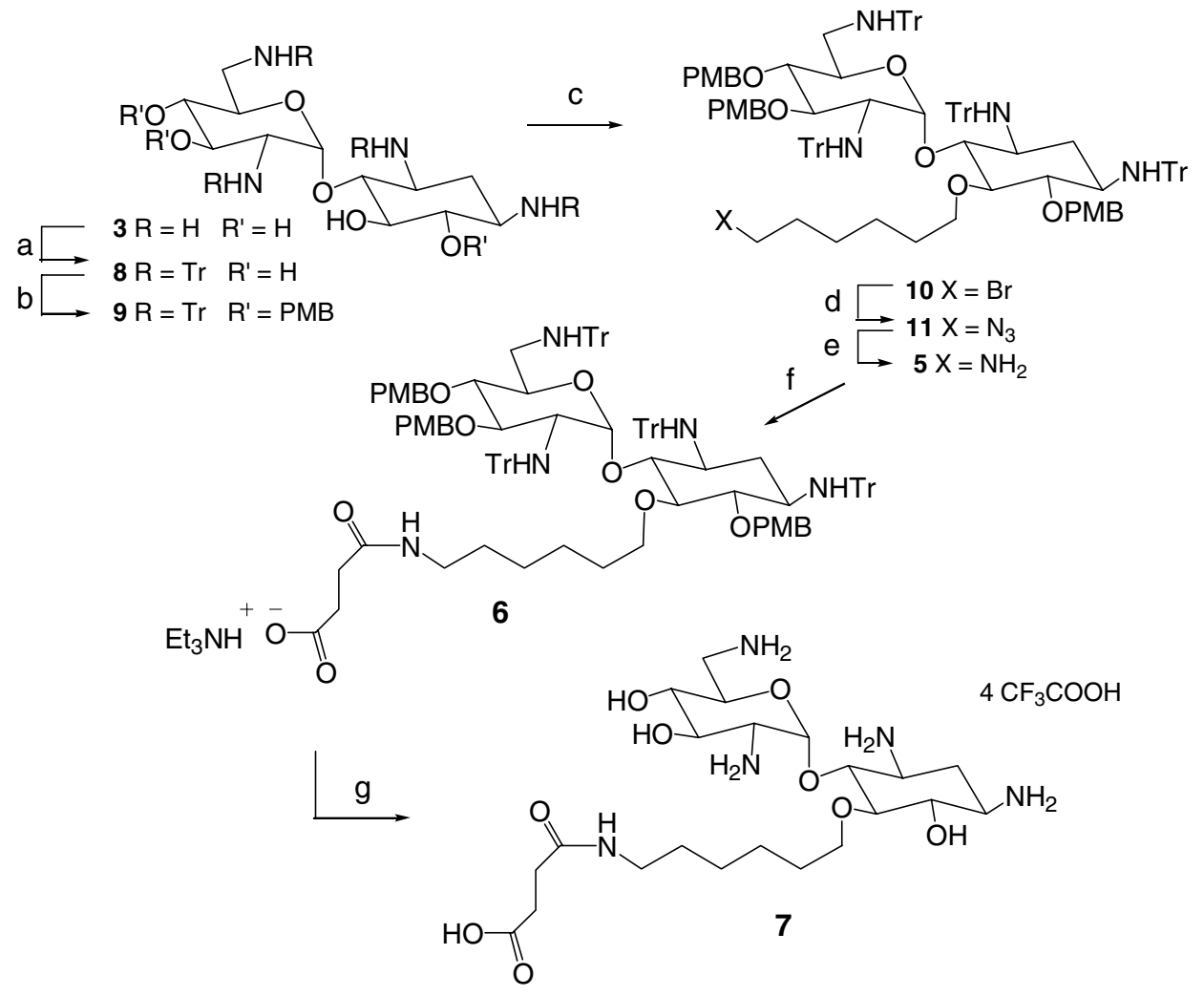

Scheme $2^{\mathrm{a}}$ : Synthesis of the protected neamine derivative $\mathbf{6}$ used in the synthesis of the PNA neamine conjugate 2. ${ }^{\text {a }}$ (a) $\mathrm{TrCl}, \mathrm{Et}_{3} \mathrm{~N}, \mathrm{DMF}, 77 \%$; (b) $\mathrm{NaH}, \mathrm{PMBCl}, \mathrm{TBAI}, \mathrm{DMF}, 47 \%$; (c) 1,6-dibromohexane (5 equi.), $\mathrm{NaH}, \mathrm{DMF}, 60^{\circ} \mathrm{C}, 76 \%$; (d) $\mathrm{NaN}_{3}, \mathrm{DMF}, 98 \%$; (e) triphenylphosphine, $\mathrm{H}_{2} \mathrm{O}$, THF, 60\%; (f) succinic anhydride, $\mathrm{Et}_{3} \mathrm{~N}, \mathrm{CH}_{2} \mathrm{Cl}_{2}, 90 \%$; (g) TFA/anisole (1:1), $81 \%$. 
Compound 5 was synthesised from neamine according to a methodology previously described. ${ }^{36}$

\section{Succinic derivatives 6 and 7}

To a solution of the neamine derivative $5(1.0 \mathrm{~g}, 0.57 \mathrm{mmol})$ in dichloromethane $(10 \mathrm{~mL})$, triethylamine $(160 \mu \mathrm{L}, 1.14 \mathrm{mmol})$ and succinic anhydride $(69 \mathrm{mg}, 0.69 \mathrm{mmol})$ were successively added. The solution was stirred for $1 \mathrm{~h}$ at room temperature and dichloromethane was added $(90 \mathrm{~mL})$. The resulting solution was washed twice with water $(50$ $\mathrm{mL}$ ), dried over $\mathrm{Na}_{2} \mathrm{SO}_{4}$ and evaporated. The residue was chromatographed on silica gel with $\mathrm{CH}_{2} \mathrm{Cl}_{2}$-methanol-triethylamine (95:4:1) to lead to compound 6 (1.0 g, $\left.0.51 \mathrm{mmol}, 90 \%\right)$ : $\mathrm{mp}$ $124-126^{\circ} \mathrm{C}$; LRMS $\left(\mathrm{FAB}^{+}, \mathrm{NBA}\right) \mathrm{m} / z=1874[\mathrm{MCOONa}+\mathrm{H}]^{+}, 1896\left[\mathrm{MCOONa}_{2}\right]^{+} ; \mathrm{HRMS}$ (electrospray) Calcd for $\mathrm{C}_{122} \mathrm{H}_{124} \mathrm{~N}_{5} \mathrm{O}_{12}[\mathrm{M}+\mathrm{H}]^{+}: 1850.9246$, found: 1850.9209 .

In order to confirm the position of the linking chain on the neamine core and to evaluate the efficiency of the deprotection step in view of the neamine-PNA conjugate synthesis, the succinic derivative 6 was deprotected $(80 \mathrm{mg}, 0.04 \mathrm{mmol})$ in a mixture TFA/anisole (50:50) at room temperature. The corresponding deprotected derivative $\mathbf{7}$ obtained was chromatographed on $\mathrm{C} 18$ reversed phase eluting with water and then on an ion exchange resin (ammonium carboxylate form) $(17 \mathrm{mg}, 81 \%), \mathrm{mp} 230{ }^{\circ} \mathrm{C} \mathrm{dec} ;{ }^{1} \mathrm{H}$ NMR $(400 \mathrm{MHz}$, $\left.\mathrm{D}_{2} \mathrm{O}\right) \delta 5.71\left(\mathrm{~d}, 1 \mathrm{H}, \mathrm{J}_{1^{\prime}, 2}{ }^{\prime}=3.7 \mathrm{~Hz}, \mathrm{H}^{\prime} 1^{\prime}\right) ; 3.92-3.72\left(\mathrm{~m}, 4 \mathrm{H}, \mathrm{H}-3^{\prime}, 4,5^{\prime}, \mathrm{CH}_{2} \mathrm{O}\right) ; 3.50-3.65$ (m, 3H, H-5, 6, $\mathrm{CH}_{2} \mathrm{O}$ ); 3.30-3.40 (m, 4H, H-3, 2', 6', 4'); 3.20 (m, 2H, H-6', 1); 3.04 (m, $2 \mathrm{H}, \mathrm{CH}_{2} \mathrm{~N}$ ); 2.30-2.42 (m, 5H, $2 \mathrm{CH}_{2}, \mathrm{H}-2_{\mathrm{eq}}$ ); 1.72 (m, 1H, H-2 $\left.{ }_{\mathrm{ax}}\right) ; 1.45$ (m, 2H, $\mathrm{CH}_{2}$ chain); 1.35 (m, 2H, $\mathrm{CH}_{2}$ chain); 1.15 (m, 4H, $\mathrm{CH}_{2}$ Chain). ${ }^{13} \mathrm{C} \mathrm{NMR}\left(100 \mathrm{MHz} ; \mathrm{D}_{2} \mathrm{O}\right) \delta 178.9$; 175.0 (C=O); 92.9 (C-1'); 82.5 (C-5); 73.3 (C-4); 72.7 (C-6); $72.0\left(\mathrm{CH}_{2} \mathrm{O}\right) ; 70.1$ (C-4'); 70.0 (C-5'); 68.3 (C-3’); 53.1 (C-2’); 49.7 (C-1); 48.8 (C-3); 39.9 (C-6’); $39.0\left(\mathrm{CH}_{2} \mathrm{NH}\right) ; 31.3$ $\left(\mathrm{CH}_{2}\right) ; 31.2\left(\mathrm{CH}_{2}\right) ; 29.1$ (C-2); 28.0; 27.8; 25.5; 24.5 (4 $\mathrm{CH}_{2}$ chain). HRMS (electrospray) Calcd for $\mathrm{C}_{22} \mathrm{H}_{44} \mathrm{~N}_{5} \mathrm{O}_{9}[\mathrm{M}+\mathrm{H}]^{+}$: 522.3139; found: 522.3132 . 


\begin{tabular}{|l|l|l|l|}
\cline { 2 - 4 } \multicolumn{1}{c|}{} & Neamine 3 & \multicolumn{2}{c|}{ Compound 7 } \\
\cline { 2 - 4 } \multicolumn{1}{c|}{} & $\delta \mathrm{ppm}$ & $\delta \mathrm{ppm}$ & $\Delta \delta \mathrm{ppm} /$ neamine \\
\hline C-3' & 68.1 & 68.3 & 0.2 \\
\hline C-4' & 70.6 & 70.1 & -0.5 \\
\hline C-5 & 69.1 & 70.0 & 0.9 \\
\hline C-4 & 77.4 & 73.3 & -4.1 \\
\hline C-5 & 75.1 & 82.5 & 7.4 \\
\hline C-6 & 72.4 & 72.7 & 0.3 \\
\hline
\end{tabular}

Table 1: ${ }^{13} \mathrm{C}$ NMR chemical shifts in neamine 3 and succinyl derivative 7 (65 and 85 ppm range). A strong deshielding effect is observed for the signal of the carbon atom C5 in compound 7.

\section{PNA-neamine conjugate 2}

The protected neamine derivative 6 (39 mg, $20 \mu \mathrm{mol})$ was dissolved in DMF (100 $\mu \mathrm{L})$ under Ar and, then, 1-[3-(dimethylaminopropyl)]-3-ethylcarbodiimide hydrochloride (EDC) (5.7 $\mathrm{mg}, 30 \mu \mathrm{mol})$ and 1-hydroxybenzotriazole (HOBt) $(4 \mathrm{mg}, 30 \mu \mathrm{mol})$ were added. The resulting solution was stirred for $15 \mathrm{~min}$ and, then, was added under Ar to the protected PNA on the solid support (PNA synthesis at $2 \mu \mathrm{M}$ scale). The mixture was stirred at room temperature for $1 \mathrm{~h}$ and filtered.

At this stage, the neamine PNA conjugate was cleaved from the solid support with concomitant deprotection by treatment with TFA/anisole (1/1) for $1 \mathrm{~h}$. The mixture was filtered and, then, diethyl ether was added to the solution to precipitate the PNAs.

HPLC purification was carried out on $\mathrm{C}_{18}$ reversed-phase column (Macherey-Nagel, $10.0 \mathrm{x}$ $25.0 \mathrm{~mm}$ ). Elution was performed at $60^{\circ} \mathrm{C}$ by building up the following gradient at a flow rate of $1.5 \mathrm{~mL} \cdot \mathrm{min}^{-1}: 0.1 \%$ TFA in acetonitrile/ $0.1 \%$ TFA in water $10 / 90 \mathrm{v} / \mathrm{v}, 10 \mathrm{~min}$, then $0.1 \%$ TFA in acetonitrile/0.1\% TFA in water/methanol 10/85/5 v/v. Under these conditions the deprotected unreacted PNA $\mathbf{1}$ and the conjugate $\mathbf{2}$ were separated and characterized by mass spectrometry. After freeze-drying, $45 \mathrm{nmol}$ of PNA 1 and $45 \mathrm{nmol}$ of conjugate 2 were obtained (50\% estimated coupling yield).

MALDI-TOF MS, conjugate 2, m/z: found, 4792.61, calculated for $\mathrm{C}_{192} \mathrm{H}_{256} \mathrm{~N}_{94} \mathrm{O}_{57}, 4792.68$. 


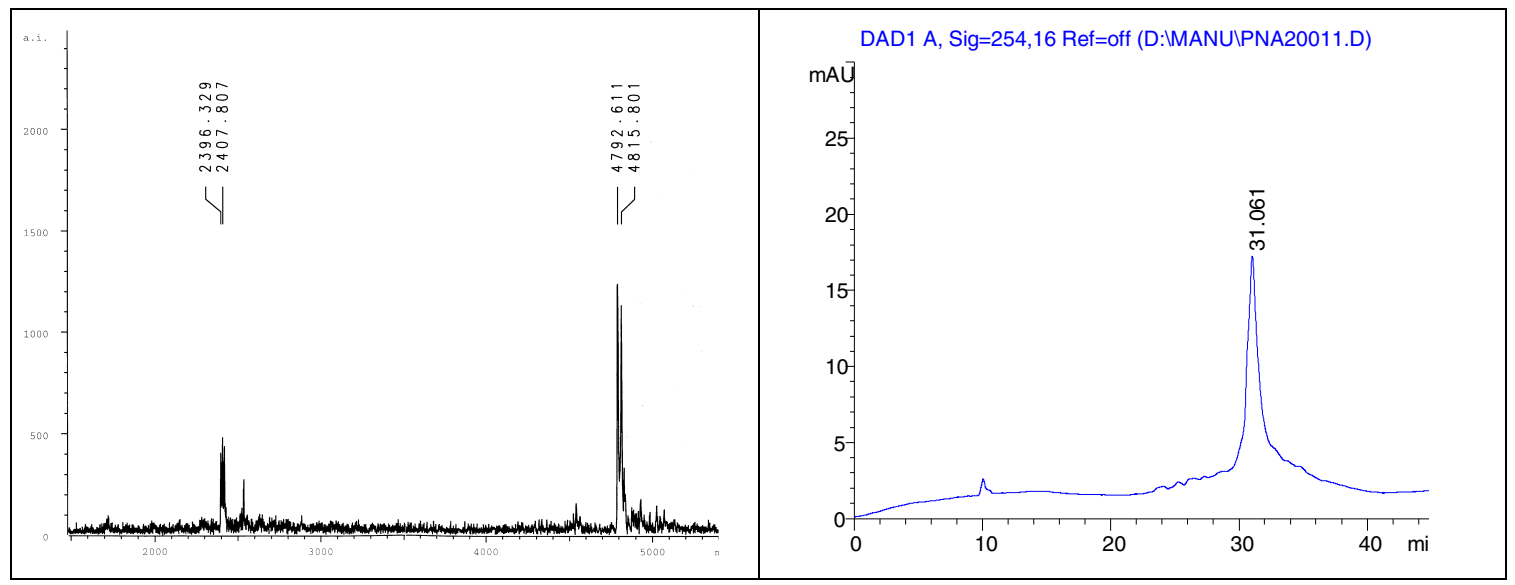

Figure 7: MALDI-TOF mass spectrum and HPLC profile of conjugate 2

\section{Biochemical and biological assays}

Preparation of HIV-1 TAR RNA: The labeled and unlabeled run-off transcript of HIV-1 TAR RNA was prepared from plasmid pEM-7 linearized with HindIII as described previously. ${ }^{14}$ The labeled transcript was purified by $10 \%$ polyacrylamide-urea gel electrophoresis. The radioactive band was excised from the gel, extracted in $0.5 \mathrm{M}$ ammonium acetate, desalted on a NAP-10 column (Pharmacia Inc), lyophilized, and dissolved in $10 \mathrm{mM}$ Tris- $\mathrm{HCl}, \mathrm{pH} 7.8,60 \mathrm{mM} \mathrm{KCl}$ and $10 \mathrm{mM}$ DTT and stored at $-70^{\circ} \mathrm{C}$. The specific radioactivity of the resulting purified transcript was determined by $A_{260}$ absorbance and Cerenkov counting.

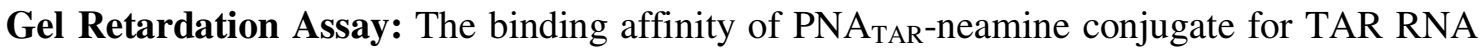
was evaluated by gel mobility shift analysis as described before. ${ }^{14,16}$ In brief, Anti-TAR PNAs at varying molar ratios were incubated with the ${ }^{32} \mathrm{P}$-labeled TAR RNA transcript (5000 Cerenkov cpm) for $1 \mathrm{~h}$ at $37^{\circ} \mathrm{C}$ in a binding buffer containing $50 \mathrm{mM}$ Tris- $\mathrm{HCl}, \mathrm{pH} 7.8,60$ $\mathrm{mM} \mathrm{KCl,} 10 \mathrm{mM}$ DTT, $10 \%$ glycerol, 0.01\% NP-40 and $500 \mathrm{ng}$ of $\mathrm{r}$ (I-C), in a final volume of $15 \mu \mathrm{l}$. Three microliters of RNA gel loading dye $(0.27 \%$ bromophenol blue and $30 \%$ glycerol) was added to the samples prior to loading. Samples were then subjected to gel retardation analysis on a native $6 \%$ polyacrylamide gel Tris-Borate buffer. The gels were routinely pre-run at $120 \mathrm{~V}$ for 30 minutes at $4^{\circ} \mathrm{C}$ in the same electrode buffer. The RNA-PNA complexes were resolved at a constant voltage of $120 \mathrm{~V}$ at $4^{\circ} \mathrm{C}$ for $3 \mathrm{~h}$ and detected by phosphorimaging. 


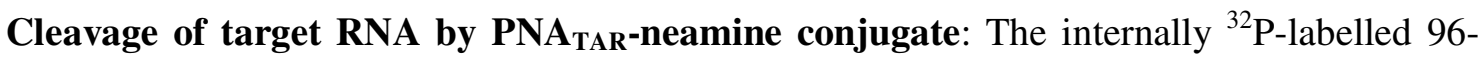
mer HIV-1 TAR RNA (125 nM) was incubated with a 4-fold excess of PNA TAR-neamine conjugate 2 in a buffer containing $50 \mathrm{mM}$ Phosphate buffer (pH 7.4), $60 \mathrm{mM} \mathrm{KCl}, 10 \mathrm{mM}$ DTT and $0.01 \%$ NP40 in a final volume of $6 \mu 1$. Following incubation at different time points at $25^{\circ} \mathrm{C}$, reaction products were resolved on a denaturing $8 \%$ polyacrylamide-7M urea gel and analyzed by phosphorimaging. The RNA ladders were generated from internally ${ }^{32} \mathrm{P}$ labeled TAR RNA by heating it at $94^{\circ} \mathrm{C}$ for $30 \mathrm{sec}$ in $50 \mathrm{mM} \mathrm{NaOH}$ followed by neutralization with equivalent amount of $\mathrm{HCl}$.

Effect of $\mathrm{Mg}^{2+}$ on the nuclease activity of $\mathrm{PNA}_{\mathrm{TAR}}$-neamine conjugate 2 . The experimental conditions were same as in panel A except that indicated concentrations of $\mathrm{MgCl}_{2}$ were also included in the incubation buffer. Control represents incubation of TAR RNA in the absence or presence of $5 \mathrm{mM} \mathrm{MgCl}_{2}$ under similar experimental conditions.

\section{Reverse Transcription of TAR RNA primed with 17-mer DNA primer}

The TAR RNA template primed with the $5{ }^{\prime}-{ }^{32} \mathrm{P}$ labeled 18 -mer DNA primer was incubated in the absence or presence of increasing concentrations of PNA-neamine conjugate 2 at $25^{\circ} \mathrm{C}$ in a reaction buffer containing $50 \mathrm{mM}$ Tris-HCl, $\mathrm{pH}$ 7.8, $10 \mathrm{mM}$ DTT, $100 \mu \mathrm{g} / \mathrm{mL}$ BSA, 60 $\mathrm{mM} \mathrm{KCl}$ and $5 \mathrm{mM} \mathrm{MgCl}_{2}$. Reverse transcription was initiated by the addition of the dNTP mix and HIV-1 RT as described before ${ }^{14}$. Unconjugated PNA and neamine were also used as controls. The reaction products were analyzed on a denaturing $8 \%$ polyacrylamide-urea gel subjected to phosphorimager analysis.

\section{Isolation of HIV-1 virions}

The pseudotyped HIV-1 virions were isolated from the culture supernatant of 293T cells transfected with pHIV-1 $1_{\text {JR-CSF-Luc }}$ env (-) and pVSV-G clones. The culture supernatant (500 $\mathrm{ml}$ ) was filtered through $0.45 \mu \mathrm{m}$ pore size membrane and centrifuged at 70,000 $\mathrm{g}$ for $45 \mathrm{~min}$. The pelleted virions were resuspended in fresh culture medium containing $10 \%$ fetal calf serum and stored at $-80^{\circ} \mathrm{C}$. HIV-1 virions were quantified by determination of the RNA copy number in the sample using Nuclesins HIV-1-QT Amplication Kit (Organon Teknika, Durham, NC). The virion number was also extrapolated from the p24 concentration considering that 2000 copies of p24 are present per virion particle. The virion number 
estimated from the RNA copy number was in agreement with the number determined by p24 quantification (1 pg p24 per 12500 virions).

Infection of CEM cells with HIV-1 S1: Lymphocyte CEM (12D7) cells were maintained in complete RPMI-1640 medium supplemented with $10 \%$ fetal bovine serum (FBS), $100 \mathrm{U} / \mathrm{ml}$ of penicillin and $100 \mu \mathrm{g} / \mathrm{ml}$ of streptomycin at $37^{\circ} \mathrm{C}$ in $5 \% \mathrm{CO}_{2}$ containing humidified air. CEM cells were infected with pseudotyped HIV-1 S1 strain and incubated in the presence of indicated concentration of PNA $\mathrm{TAR}_{\mathrm{TA}}$-neamine conjugate or naked PNA. Cells were harvested after $48 \mathrm{~h}$ post-infection, lysed and assayed for luciferase activity as described before. ${ }^{14}$ AntiTAR PNA-transportan conjugate known to inhibit HIV-1 replication ${ }^{14}$ was used as a positive control.

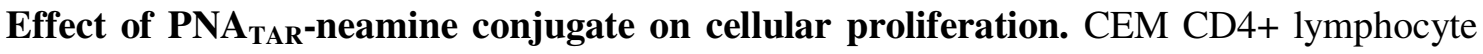

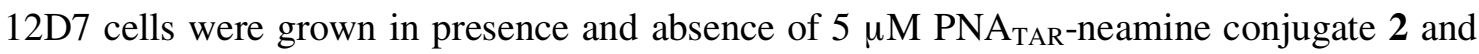
supplemented with $10 \mu \mathrm{Ci}$ of $\left[\right.$ methyl- $\left.{ }^{3} \mathrm{H}\right]$ thymidine $/ \mathrm{ml}(64.2 \mathrm{Ci} / \mathrm{mmol})$. At the indicated time points the cells were harvested and the protein content was determined using Bio-Rad protein assay kit. The cellular DNA was precipitated by $10 \%$ trichloroacetic acid and the acid insoluble precipitate was collected on glass fibre filter. Total amount of radioactivity was determined by liquid scintillation counting.

\section{Determination of $\left[{ }^{3} \mathrm{H}\right]$ thymidine incorporation into cellular DNA in chronically $\mathrm{HIV}-1$} infected $\mathbf{H 9}$ cells. Cellular proliferation of infected CEM cells in the presence of PNA $\mathrm{TAR}_{\text {- }}$ neamine conjugate 2 was determined by estimating the levels of $\left[{ }^{3} \mathrm{H}\right]$ thymidine incorporated in their nuclei. Briefly, freshly split cells were grown in the presence or absence of the conjugate (5 $\mu \mathrm{M}$ concentration) and supplemented with $10 \mu \mathrm{Ci}$ of $\left[\right.$ methyl $\left.-{ }^{3} \mathrm{H}\right]$ thymidine $/ \mathrm{ml}(64.2 \mathrm{Ci} / \mathrm{mmol})$. The cells were withdrawn at different time points and the cell number determined using a coulter counter. The cells were harvested, washed with PBS, and resuspended in $200 \mu 1$ of lysis buffer containing $1 \%$ NP-40 in PBS. The nucleic acids were precipitated by adding cold $10 \%$ trichloroacetic acid (TCA). Precipitates were collected on GF/C glass fiber filters (Whatman, Inc., Maidstone, Kent, England) and washed extensively with ice-cold 10\% TCA and once in $70 \%$ ethanol. Filters were dried, placed in scintillation vials, and counted in the scintillation counter. Protein content in each lysate was estimated by the Bio-Rad protein assay. Results were expressed as counts per minute per milligram of protein. 